\title{
Stevens-Johnson syndrome induced by combined treatment: carbamazepine and cranial radiation therapy. A case of EMDART?
}

\section{Zespół Stevensa-Johnsona wywołany leczeniem karbamazepiną i radioterapią głowy. Przypadek zespołu EMDART?}

Anna Waśkiel', Katarzyna Dyttus-Cebulok², Katarzyna Polak-Witka', Małgorzata Pawłowska-Kisiel', Zbigniew Szutkowski², Lidia Rudnicka', Małgorzata Olszewska'

\author{
'Department of Dermatology, Medical University of Warsaw, Poland \\ 2Department of Teleradiotherapy, Maria Skłodowska-Curie Memorial Cancer Center, Warsaw, Poland \\ 'Katedra i Klinika Dermatologiczna Warszawskiego Uniwersytetu Medycznego, Polska \\ ${ }^{2} Z$ akład Teleradioterapii Centrum Onkologii - Instytutu im. Marii Skłodowskiej-Curie w Warszawie, Polska
}

\section{CORRESPONDING AUTHOR/ ADRES DO KORESPONDENCJI: prof. dr hab. n. med. \\ Lidia Rudnicka \\ Katedra i Klinika Dermatologiczna \\ Warszawski Uniwersytet \\ Medyczny \\ ul. Koszykowa 82 A \\ 02-008 Warszawa, Polska \\ e-mail: lidiarudnicka@gmail.com}

\begin{abstract}
Introduction. In 1988, Delattre et al. described the first case of erythema multiforme associated with phenytoin and cranial radiation therapy. In 2004, Ahmed et al. coined the term EMPACT syndrome (Erythema Multiforme associated with Phenytoin And Cranial Radiation Therapy).

Case report. A 61-year-old patient with glioblastoma was admitted to our hospital with mucosal and cutaneous involvement diagnosed as Stevens-Johnson syndrome induced by combined treatment consisting of carbamazepine and radiation therapy. The cutaneous and mucosal lesions were successfully treated with prednisone and discontinuation of carbamazepine, chemotherapy and radiation therapy.

Conclusions. A discussion is ongoing in the literature about a possible association between radiation therapy, anticonvulsant treatment and Stevens-Johnson syndrome. We present a rare case of Stevens-Johnson syndrome induced by carbamazepine combined with radiation therapy and suggest a new acronym - EMDART (Erythema Multiforme associated with Drug And Radiation Therapy) for the description of this entity, as a wider term compared to EMPACT. The newly suggested term includes all diseases in the spectrum of erythema multiforme (also Stevens-Johnson syndrome and toxic epidermal necrolysis) induced by all drugs (not only phenytoin) in association with radiation therapy in all locations.
\end{abstract}

\section{STRESZCZENIE}

Wprowadzenie. W 1988 r. Delattre i wsp. opisali pierwszy przypadek rumienia wielopostaciowego związanego ze stosowaniem fenytoiny i radioterapii głowy. W 2004 r. Ahmed i wsp. stworzyli akronim EMPACT (Erythema Multiforme associated with Phenytoin And Cranial Radiation Therapy).

Opis przypadku. 61-letni pacjent z glejakiem wielopostaciowym został przyjęty do Kliniki Dermatologicznej z powodu zmian skórno-śluzówkowych rozpoznanych jako zespół Stevensa-Johnsona wywołany kar- 
bamazepiną stosowaną w skojarzeniu z radioterapią głowy. W leczeniu zastosowano prednizon, a także zaprzestano podawania karbamazepiny, chemio- i radioterapii, uzyskując ustąpienie zmian śluzówkowych i skórnych.

Wnioski. W piśmiennictwie trwa dyskusja o potencjalnym związku pomiędzy radioterapią, lekami przeciwdrgawkowymi oraz występowaniem zespołu Stevensa-Johnsona. Prezentujemy rzadki przypadek zespołu Stevensa-Johnsona wywołanego karbamazepiną stosowaną w skojarzeniu z radioterapią głowy oraz proponujemy nowy akronim EMDART (Erythema Multiforme associated with Drug And Radiation Therapy) jako pojęcie szersze niż EMPACT. Nowy termin obejmuje wszystkie choroby ze spektrum rumienia wielopostaciowego (również zespół Stevensa-Johnsona oraz toksyczną nekrolizę naskórka) związane ze stosowaniem także innych leków niż fenytoina $\mathrm{w}$ skojarzeniu $\mathrm{z}$ radioterapią we wszystkich lokalizacjach.

Key words: EMPACT, erythema multiforme, phenytoin.

Słowa kluczowe: EMPACT, rumień wielopostaciowy, fenytoina.

\section{INTRODUCTION}

Erythema multiforme, Stevens-Johnson syndrome and toxic epidermal necrolysis are acute mucocutaneous disorders which can be induced by infections or drugs [1]. Cutaneous reactions triggered by radiation therapy are a well-recognized phenomenon. Acute radiation reactions characterized by erythema and desquamation, or late reactions including teleangiectasias and fibrosis, are observed in 5\% of patients either during or after radiation therapy [2]. Severe inflammatory dermatoses such as erythema multiforme, Stevens-Johnson syndrome or toxic epidermal necrolysis are rarely triggered by radiotherapy alone $[2,3]$.

\section{OBJECTIVE}

We present the case of a patient with glioblastoma complicated by epilepsy who developed Stevens-Johnson syndrome after combined treatment consisting of carbamazepine and cranial radiation therapy.

\section{CASE REPORT}

We present a 61-year-old patient with a threemonth history of glioblastoma who was referred to our hospital with severe involvement of cutaneous and mucosal membranes corresponding to Stevens-Johnson syndrome. The patient underwent tumour surgery. Twenty-seven days after the sur-

\section{WPROWADZENIE}

Rumień wielopostaciowy, zespół Stevensa-Johnsona oraz toksyczna nekroliza naskórka są ostrymi chorobami przebiegającymi z zajęciem skóry i błon śluzowych, wywoływanymi zakażeniem lub przyjmowaniem niektórych leków [1]. Reakcje skórne występujące w związ$\mathrm{ku} \mathrm{z}$ radioterapią są powszechnie znanym zjawiskiem. Ostre reakcje popromienne w postaci skórnych zmian rumieniowo-złuszczających bądź późne reakcje obejmujące teleangiektazje i włóknienie obserwuje się u 5\% pacjentów $\mathrm{w}$ trakcie radioterapii lub po jej zakończeniu [2]. Ciężkie choroby zapalne skóry, takie jak rumień wielopostaciowy, zespół Stevensa-Johnsona oraz toksyczna nekroliza naskórka, rzadko występują u pacjentów poddawanych wyłącznie radioterapii $[2,3]$.

\section{CEL PRACY}

Przedstawiamy przypadek pacjenta z glejakiem wielopostaciowym powikłanym padaczką, u którego rozpoznano zespół Stevensa-Johnsona wywołany karbamazepiną stosowaną w skojarzeniu z radioterapią głowy.

\section{OPIS PRZYPADKU}

Prezentujemy przypadek 61-letniego mężczyzny, ze zdiagnozowanym 3 miesiące wcześniej glejakiem wielopostaciowym, który został przyjęty do naszego ośrodka z powodu zmian w obrębie skóry i błon śluzowych rozpoznanych jako zespół Stevensa-Johnsona. Pacjent został poddany leczeniu chirurgicznemu. Dwadzieścia siedem dni po zabiegu chirurgicznym z powodu na- 
gical procedure the patient developed epilepsy, so oral carbamazepine was started (300 mg twice daily). Fifty days after the surgery, oral temozolomide (135 mg once daily), oral dexamethasone (4 mg once daily), and cranial radiation therapy (total dose 60 Gy; fractional dose $=200$ cGy) were initiated. Fifty-four days after the surgery (on the $4^{\text {th }}$ day of radiation therapy and $27^{\text {th }}$ day of carbamazepine treatment) mucosal and cutaneous lesions developed on the skin on the scalp and neck, and then spread to the trunk and the upper and lower limbs.

On admission, he presented with erythematous and oedematous cutaneous lesions $(70 \%$ of body surface area) with epidermal detachment $(<10 \%$ of body surface area), erosions of the mucous membranes of the nose and oral cavity, haemorrhagic crusts on the lips, and involvement of conjunctiva with the presence of mucopurulent exudate (Figs. 1 A, B). The diagnosis of Stevens-Johnson syndrome was established. Subsequently, temozolomide and radiation therapy were discontinued and carbamazepine was substituted with oral valproic acid (500 mg twice daily). The patient was started on oral prednisone $(0.6 \mathrm{mg} / \mathrm{kg}$ daily). On account of coexisting fever (to $39^{\circ} \mathrm{C}$ ), antibiotics (oral clarithromycin, $500 \mathrm{mg}$ twice daily; oral metronidazole, $500 \mathrm{mg}$ three times daily) and antifungal medication (oral fluconazole $100 \mathrm{mg}$ once daily) were administered. One week after admission, prednisone was tapered gradually. Complete resolution of the mucocutaneous lesions was achieved within 2 weeks.

\section{DISCUSSION}

In 1988, Delattre et al. described the first case of erythema multiforme associated with phenytoin and cranial radiation therapy [4]. In 2004, Ahmed et al. coined the term EMPACT syndrome - Erythe- padów padaczkowych u pacjenta wdrożono doustne leczenie karbamazepiną (300 mg dwa razy na dobę). Po 50 dniach od operacji rozpoczęto doustne leczenie temozolomidem (135 mg raz na dobę) i deksametazonem (4 mg raz na dobę) oraz radioterapię głowy (dawka całkowita 60 Gy; dawka frakcyjna = 200 cGy). Po 54 dniach od operacji (w 4. dniu radioterapii i w 27. dniu leczenia karbamazepiną) u pacjenta wystąpiły zmiany błon śluzowych oraz zmiany skórne zlokalizowane początkowo na skórze owłosionej głowy i skórze gładkiej karku, rozprzestrzeniające się następnie na tułów oraz kończyny górne i dolne.

Przy przyjęciu u pacjenta stwierdzono skórne zmiany rumieniowo-obrzękowe (70\% powierzchni ciała), którym towarzyszyło oddzielanie się naskórka ( $<10 \%$ powierzchni ciała), nadżerki w obrębie błon śluzowych nosa i jamy ustnej, krwotoczne strupy umiejscowione na czerwieni wargowej oraz zajęcie spojówek z obecnością śluzowo-ropnej wydzieliny (ryc. 1 A, B). Ustalono rozpoznanie zespołu Stevensa-Johnsona. Odstawiono temozolomid oraz radioterapię, a karbamazepinę zastąpiono kwasem walproinowym podawanym doustnie (500 $\mathrm{mg}$ dwa razy na dobę). Wdrożono doustne leczenie prednizonem (0,6 mg/kg m.c./ dobę). Ze względu na wystąpienie goraczki (do $39^{\circ} \mathrm{C}$ ) zastosowano antybiotykoterapię (klarytromycyna doustnie $500 \mathrm{mg}$ dwa razy na dobę, metronidazol doustnie $500 \mathrm{mg}$ trzy razy na dobę) oraz leczenie przeciwgrzybicze (flukonazol doustnie $100 \mathrm{mg}$ raz na dobę). Po tygodniu rozpoczęto stopniowe zmniejszanie dawki prednizonu. W ciągu 2 tygodni stwierdzono całkowite ustąpienie zmian skórno-śluzówkowych.

\section{OMÓWIENIE}

W 1988 r. Delattre i wsp. opisali pierwszy przypadek rumienia wielopostaciowego związanego z leczeniem fenytoiną oraz radioterapią głowy [4]. W $2004 \mathrm{r}$. Ahmed i wsp. stworzyli akronim EMPACT (Erythema
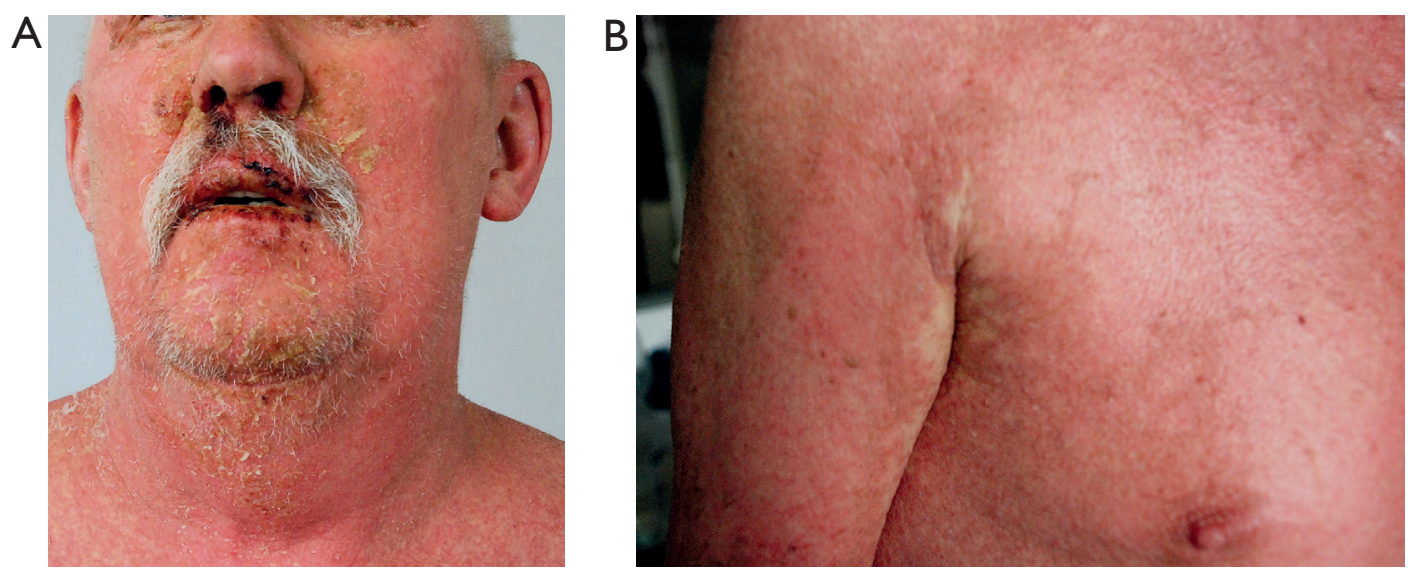

Figure I A, B. Mucocutaneous lesions in a patient with Stevens-Johnson syndrome

Rycina I A, B. Zmiany śluzówkowe i skórne u pacjenta z zespołem Stevensa-Johnsona 
ma Multiforme associated with Phenytoin And Cranial Radiation Therapy [5].

The pathogenesis of the EMPACT syndrome is still unknown. However, type IV hypersensitivity induced by phenytoin and its metabolites, which is exacerbated by concurrent radiation therapy, is postulated as a possible mechanism [6]. Phenytoin induces the microsomal cytochrome P450 (CYP-3A) and generates oxidative intermediates (arene oxide metabolites) that are subsequently detoxified by epoxide hydrolase. Concurrent phenytoin use and radiation therapy may cause dysfunction of epoxide hydrolase, which impairs the detoxification of the oxidative intermediates. These intermediates may bind to cell macromolecules, thereby forming haptens that can induce an immune response and/ or directly damage cells [5]. It has also been hypothesized that radiation may deplete the pool of suppressor T lymphocytes. Moreover, radiation can affect the hypothalamic-pituitary axis, which may, in turn, trigger skin reactions [7].

In total, 49 cases of erythema multiforme, Stevens-Johnson syndrome or toxic epidermal necrolysis which developed shortly after starting phenytoin and cranial radiotherapy have been described in the literature [6-16]. In all of the reported cases, skin lesions appeared initially at the site of cranial radiation and spread to other sites within days [11]. The affected patients were 22-76 years old (mean: 47 years). The period from the initiation of radiation therapy to the development of skin lesions was from 5 to 35 days (mean: 21 days), and the time from phenytoin inclusion ranged from 8 to 180 days (mean: 38 days). In most cases, the lesions were described as Stevens-Johnson syndrome (53\%, 26 cases). Erythema multiforme was observed in $16.5 \%$ (8 cases), and toxic epidermal necrolysis in $24.5 \%$ (12 cases). In some cases, Stevens-Johnson syndrome/toxic epidermal necrolysis overlap (6\%, 3 cases) was observed. The extent and severity of the cutaneous lesions were not associated with radiation dose, phenytoin dose or the type and origin of intracranial malignancy.

Erythema multiforme, Stevens-Johnson syndrome or toxic epidermal necrolysis have been also reported in patients who used drugs other than phenytoin (most commonly phenobarbital, amifostine) or received radiation therapy to other body parts $[3,17]$.

A limited number of case reports describing erythema multiforme, Stevens-Johnson syndrome or toxic epidermal necrolysis in association with carbamazepine and concurrent radiation therapy were published in the literature [18-20].

The pathogenesis of skin lesions occurring in association with carbamazepine and radiation thera-
Multiforme associated with Phenytoin And Cranial Radiation Therapy) [5].

Patogeneza zespołu EMPACT nie została dotychczas poznana. Jako potencjalny mechanizm postuluje się jednak nadwrażliwość typu IV wywoływaną przez fenytoinę i jej metabolity, która ulega nasileniu w przypadku jednocześnie stosowanej radioterapii [6]. Fenytoina jest induktorem mikrosomalnego cytochromu P450 (CYP-3A) i generuje oksydacyjne produkty przejściowe (metabolity - tlenki arenowe), które następnie ulegają detoksyfikacji przez hydrolazę epoksydową. Równoczesne leczenie fenytoiną i radioterapią może zakłócać działanie hydrolazy epoksydowej, co osłabia proces detoksyfikacji oksydacyjnych produktów przejściowych. Z kolei produkty przejściowe, wiążąc się z makrocząsteczkami komórkowymi, tworzą hapteny, które mogą wywoływać reakcję immunologiczną i/lub powodować bezpośrednie uszkodzenia komórek [5]. Wysuwano również hipotezę, że wskutek promieniowania może dochodzić do zmniejszenia puli limfocytów T supresorowych. Ponadto oddziaływanie promieniowania na oś podwzgórze-przysadka może także odpowiadać za występowanie zmian skórnych [7].

W piśmiennictwie opisano łącznie 49 przypadków rumienia wielopostaciowego, zespołu Stevensa-Johnsona lub toksycznej nekrolizy naskórka, które wystąpiły wkrótce po wdrożeniu leczenia fenytoiną w skojarzeniu z radioterapią głowy [6-16]. We wszystkich opisanych przypadkach zmiany skórne pojawiały się początkowo w miejscu napromieniania i w ciągu kilku dni rozprzestrzeniły się, obejmując inne lokalizacje [11]. Wiek pacjentów, u których odnotowano zmiany, wynosił 22-76 lat (średnia: 47 lat). Czas od rozpoczęcia radioterapii do wystąpienia zmian skórnych wynosił 5-35 dni (średnia: 21 dni), a czas od wdrożenia fenytoiny - od 8 do 180 dni (średnia: 38 dni). U większości pacjentów (26 przypadków, 53\%) zmiany odpowiadały zespołowi Stevensa-Johnsona. Rumień wielopostaciowy rozpoznano u 16,5\% pacjentów (8 przypadków), a toksyczną nekrolizę naskórka - u 24,5\% chorych (12 przypadków). W niektórych przypadkach stwierdzono nakładanie się zespołu Stevensa-Johnsona i toksycznej nekrolizy naskórka (3 przypadki, 6\%). Zasięg i nasilenie zmian skórnych nie zależały od dawki napromieniania, dawki fenytoiny oraz typu i pochodzenia złośliwego nowotworu śródczaszkowego.

Rumień wielopostaciowy, zespół Stevensa-Johnsona lub toksyczną nekrolizę naskórka obserwowano także u chorych przyjmujących leki inne niż fenytoina (zazwyczaj fenobarbital lub amifostynę) lub poddanych radioterapii w innych lokalizacjach [3, 17].

W piśmiennictwie opisano niewielką liczbę przypadków rumienia wielopostaciowego, zespołu Stevensa-Johnsona lub toksycznej nekrolizy naskórka, występujących w przebiegu leczenia karbamazepiną i jednocześnie stosowanej radioterapii [18-20]. 
py might be considered to be similar to the pathogenesis of the EMPACT syndrome. Carbamazepine, as phenytoin, is an aromatic anticonvulsant drug that induces cytochrome P450 (CYP-3A) and produces oxidative reactive intermediates which may be implicated in hypersensitivity reactions such as erythema multiforme, Stevens-Johnson syndrome or toxic epidermal necrolysis. Moreover, carbamazepine has shown cross-sensitivity with phenytoin [21].

The influence of radiotherapy on the development of cutaneous eruptions remains ambiguous. Radiotherapy has been described as a trigger factor for severe inflammatory dermatoses such as erythema multiforme, Stevens-Johnson syndrome or toxic epidermal necrolysis [2, 3], however, the protective role of radiotherapy in the development of cutaneous adverse drug reactions has also been reported in the literature. There are a number of case reports describing skin reactions to medications with spared irradiated fields $[22,23]$. The protective role of radiotherapy may be associated with radiation-induced local immunosuppression through the inactivation of cytotoxic T lymphocytes [22].

\section{CONCLUSIONS}

In conclusion, we suggest the acronym EMDART (Erythema Multiforme associated with Drugs And Radiation Therapy) to describe cases of Stevens-Johnson syndrome induced by concurrent treatment consisting of radiotherapy and drugs. The newly suggested term includes all diseases in the spectrum of erythema multiforme (also Stevens-Johnson syndrome and toxic epidermal necrolysis) induced by all drugs (not only phenytoin) in association with radiotherapy in all locations.

\section{CONFLICT OF INTEREST}

The authors declare no conflict of interest.
Można uznać, że patogeneza zmian skórnych związanych ze stosowaniem karbamazepiny i radioterapii jest zbliżona do patogenezy zespołu EMPACT. Karbamazepina, podobnie jak fenytoina, jest lekiem przeciwdrgawkowym należącym do związków aromatycznych. Indukuje cytochrom P450 (CYP-3A) i wytwarza oksydacyjne reaktywne produkty przejściowe, które mogą uczestniczyć w inicjowaniu reakcji nadwrażliwości, takich jak rumień wielopostaciowy, zespół Stevensa-Johnsona lub toksyczna nekroliza naskórka. Należy także dodać, że karbamazepina wykazuje wrażliwość krzyżową z fenytoiną [21].

Wpływ radioterapii na wystąpienie zmian skórnych nadal jest nieznany. Radioterapię opisywano jako czynnik wyzwalający ciężkie dermatozy zapalne, takie jak rumień wielopostaciowy, zespół Stevensa-Johnsona czy toksyczna nekroliza naskórka [2, 3], jednak w piśmiennictwie można także znaleźć doniesienia o ochronnej roli radioterapii w rozwoju skórnych niepożądanych działań polekowych. Opisano przypadki, w których reakcje skórne spowodowane przyjmowaniem leków nie wystąpiły w miejscach napromienianych $[22,23]$. Ochronna rola radioterapii może się wiązać z indukowanym przez napromieniowanie miejscowym działaniem immunosupresyjnym wynikającym z dezaktywacji cytotoksycznych limfocytów T [22].

\section{WNIOSKI}

Podsumowując - proponujemy akronim EMDART (Erythema Multiforme associated with Drugs And Radiation Therapy) opisujaccy przypadki występowania zmian skórno-śluzówkowych wywołanych jednoczesnym stosowaniem radioterapii i leczenia farmakologicznego. Proponowany akronim obejmuje wszystkie choroby ze spektrum rumienia wielopostaciowego (również zespół Stevensa-Johnsona oraz toksyczną nekrolizę naskórka), które mają związek ze stosowaniem wszystkich leków (nie tylko fenytoiny) w skojarzeniu z radioterapią, niezależnie od lokalizacji.

\section{KONFLIKT INTERESÓW}

Autorzy deklarują brak konfliktu interesów.

\section{References}

\section{Piśmiennictwo}

1. Auquier-Dunant A., Mockenhaupt M., Naldi L., Correia O., Schroder W., Roujeau J.C., et al.: Correlations between clinical patterns and causes of erythema multiforme majus, Stevens-Johnson syndrome, and toxic epidermal necrolysis: results of an international prospective study. Arch Dermatol 2002, 138, 1019-1024.

2. Owczarczyk-Saczonek A.B., Placek W.J., Rybak-d'Obyrn J., Wygonowska E.: Toksyczna nekroliza naskórka sprowokowana radioterapią. Przegl Dermatol/Dermatol Rev 2013, 100, 363-370.

3. Yoshitake T., Nakamura K., Shioyama Y., Sasaki T., Ooga S., Abe M., et al.: Erythema multiforme and Stevens-Johnson syndrome following radiotherapy. Radiat Med 2007, 25, 27-30.

4. Delattre J.Y., Safai B., Posner J.B.: Erythema multiforme and Stevens-Johnson syndrome in patients receiving cranial irradiation and phenytoin. Neurology 1988, 38, 194-198. 
5. Ahmed I., Reichenberg J., Lucas A., Shehan J.M.: Erythema multiforme associated with phenytoin and cranial radiation therapy: a report of three patients and review of the literature. Int J Dermatol 2004, 43, 67-73.

6. Ahmed I., Biswas A., Krishnamurthy S., Julka P.K.: Toxic epidermal necrolysis in a patient receiving concurrent phenytoin and whole brain and thoracic radiotherapy. Saudi Med J 2014, 35, 1393-1395.

7. Bilgili S.G., Calka O., Karadag A.S., Burakgazi A.Z.: EMPACT syndrome. Cutan Ocul Toxicol 2011, 30, 328-330.

8. Fernandez F.A., Pintor E., Quesada R., Garces F.J.: Toxic epidermal necrolysis induced by phenytoin and whole brain radiotherapy. Actas Dermosifiliogr 2007, 98, 483-485.

9. Goyal S., Biswas A., Puri T., Mohanti B.K.: Stevens-Johnson syndrome following concurrent phenytoin and holocranial radiotherapy. Acta Oncol 2010, 49, 259-260.

10. Kandil A.O., Dvorak T., Mignano J., Wu J.K., Zhu J.J.: Multifocal Stevens-Johnson syndrome after concurrent phenytoin and cranial and thoracic radiation treatment - a case report. Radiat Oncol 2010, 5, 49.

11. Aydogan K., Vatansever S., Adim S.B., Saricaoglu H.: Empact syndrome: a case report and review of the literature. Int J Dermatol 2010, 49, 945-949.

12. Fidan E., Fidan M., Ozdemir F., Kavgaci H., Aydin F.: Phenytoin- and cranial radiotherapy-induced toxic epidermal necrolysis treated with combination therapy: systemic steroid and intravenous immunoglobulin. Med Oncol 2012, 29, 686-689.

13. Elazzazy S., Abu Hassan T., El Seid A., Jacob C.M.: Toxic epidermal necrolysis associated with antiepileptic drugs and cranial radiation therapy. Case Rep Oncol Med 2013, 2013, 415031.

14. Rajan U., Sasidharanpillai S., Khader A., Mohan M.: EMPACT syndrome. Indian J Dermatol Venereol Leprol 2014, 80, 354356.

15. Kazanci A., Tekkok I.H.: Phenytoin induced erythema multiforme after cranial radiation therapy. J Korean Neurosurg Soc 2015, 58, 163-166.

16. Vilas-Sueiro A., Vazquez-Osorio I., Suarez-Penaranda J.M., Sanchez-Aguilar D.: Erythema multiforme associated with phenytoin and cranial radiation therapy (EMPACT syndrome) in a patient with lung cancer. Actas Dermosifiliogr 2016, 107, 169-170.

17. Vern-Gross T.Z., Kowal-Vern A.: Erythema multiforme, Stevens Johnson syndrome, and toxic epidermal necrolysis syndrome in patients undergoing radiation therapy: a literature review. Am J Clin Oncol 2014, 37, 506-513.

18. Hoang-Xuan K., Delattre J.Y., Poisson M.: Stevens-Johnson syndrome in a patient receiving cranial irradiation and carbamazepine. Neurology 1990, 40, 1144-1145.

19. Chevenet C., Ferrier M.C., Reverte M., Tao Y., Perea R., Roger H., et al.: Erythema multiforme caused by the combination of carbamazepine and cerebral irradiation. Ann Dermatol Venereol 1992, 119, 929-931.

20. Kaczmarska-Turek D., Bartnik P., Kacperczyk J., Orlewski J., Olszewska M., Krasnodebska-Kiljanska M.: Toxic epidermal necrolysis in patient with malignant astrocytoma. Pol Merkur Lekarski 2016, 40, 25-27.

21. Ruggiero A., Buonuomo P.S., Maurizi P., Cefalo M.G., Corsello M., Riccardi R.: Stevens-Johnson syndrome in children receiving phenobarbital therapy and cranial radiotherapy. J Neurooncol 2007, 85, 213-215.

22. Hafiji J., Orpin S., Roberts C., Heagerty A., Lewis H.: Radiotherapy: a protective role for toxic epidermal necrolysis? Br J Dermatol 2010, 162, 1139-1141.

23. Musio D., Parisi E., Dionisi F., Parisi G., Caiazzo R., Bulzonetti N., et al.: Irradiated fields spared Stevens-Johnson syndrome in a patient undergoing radiotherapy for bone metastases. Jpn J Radiol 2009, 27, 103-106.

Received: 19.01 .2017

Accepted: 2.06 .2017

Otrzymano: $19.01 .2017 \mathrm{r}$

Zaakceptowano: $2.06 .2017 \mathrm{r}$

How to cite this article

Waśkiel A., Dyttus-Cebulok K., Polak-Witka K., Pawłowska-Kisiel M., Szutkowski Z., Rudnicka L., Olszewska M.: Stevens-Johnson syndrome induced by combined treatment: carbamazepine and cranial radiation therapy. A case of EMDART? Dermatol Rev/Przegl Dermatol 2017, 104, 331-336. DOI: https://doi.org/10.5114/dr.2017.68780. 